
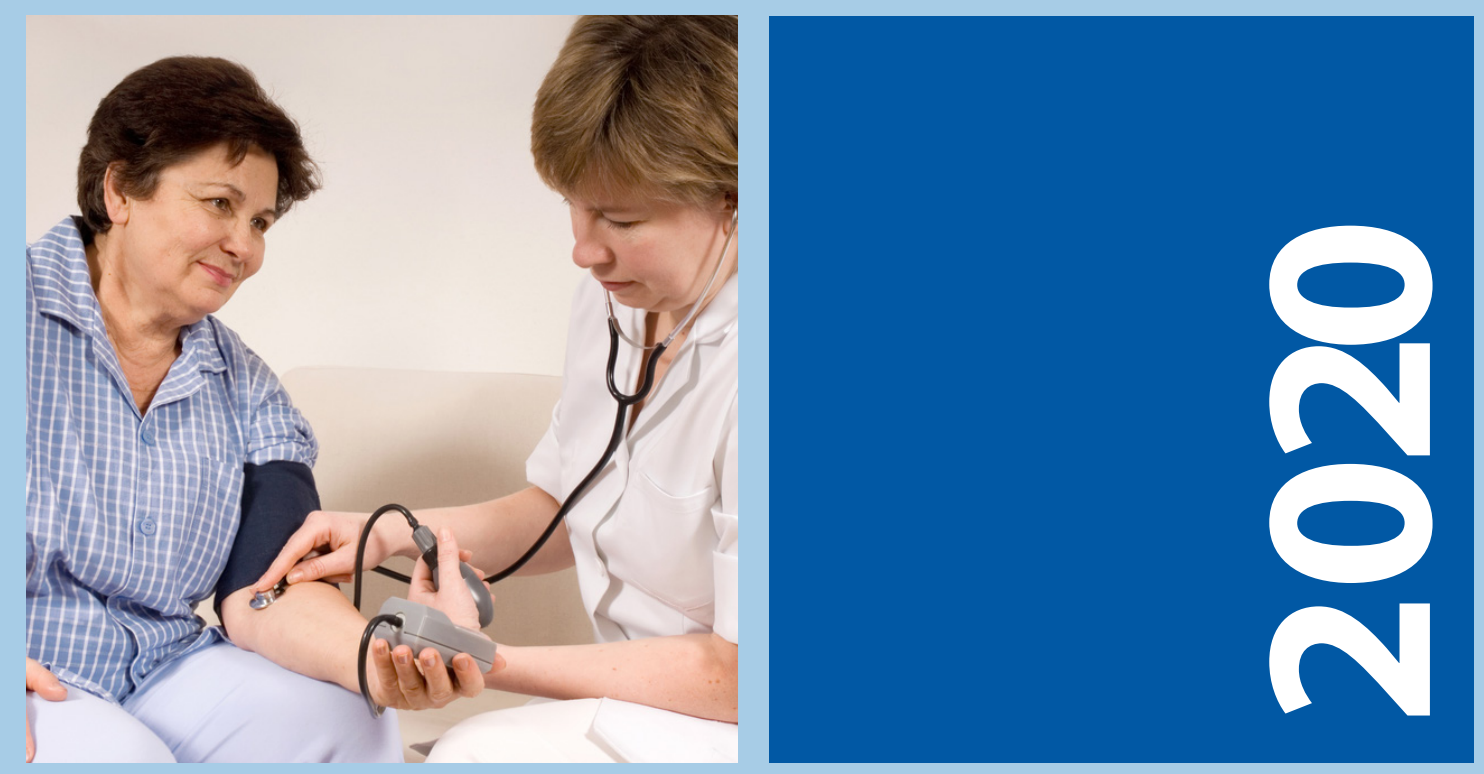

\title{
Patterns in health service utilisation: Results from Wave 5 of The Irish Longitudinal Study on Ageing
}

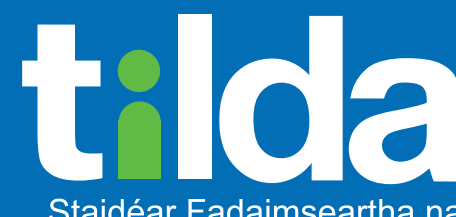

Staidéar Fadaimseartha na hÉireann um Dhul in Aois

The Irish Longitudinal Study on Ageing 


\section{Patterns in health service utilisation: Results from Wave 5 of The Irish Longitudinal Study on Ageing}

Lorna Roe, Christine McGarrigle, Belinda Hernández, Aisling O’Halloran, Siobhan Scarlett, Mark Ward, Charles Normand, Rose Anne Kenny

The Irish Longitudinal Study on Ageing (TILDA) Trinity College, Dublin

On behalf of the TILDA team

April 2020 
Copyright (C) The Irish Longitudinal Study on Ageing 2020

The Irish Longitudinal Study on Ageing

Trinity College Dublin

Dublin 2

Tel: +35318962509

Email: tilda@tcd.ie

Website: www.tilda.ie

ISBN: 978-1-907894-29-9

https://www.doi.org/10.38018/TildaRe.2020-04 


\section{Acknowledgements}

We would like to acknowledge the vision and commitment of our study funders, the Department of Health, the Health Research Board, Science Foundation Ireland, The Atlantic Philanthropies, and Irish Life plc. We would like to state that any views expressed in this report are not necessarily those of the Department of Health or of the Minister for Health. We would also like to thank the TILDA participants without whom this research would not be possible. 


\section{Contents}

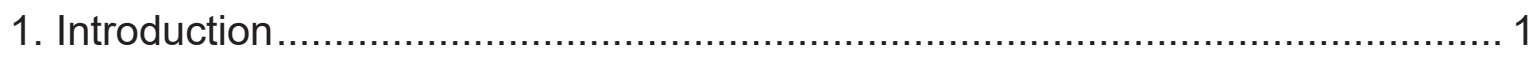

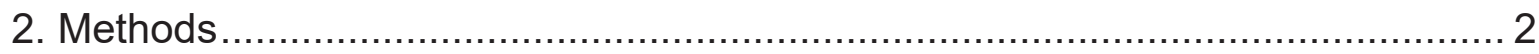

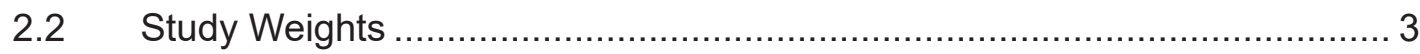

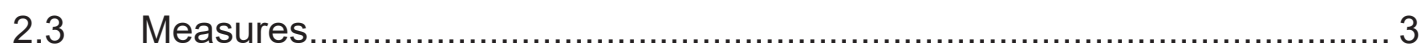

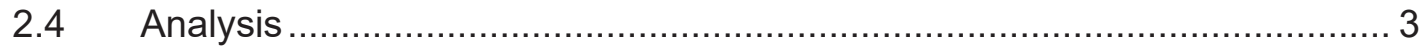

3.1 Health service utilisation: national estimates....................................... 7

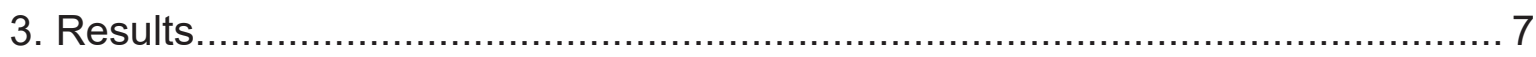

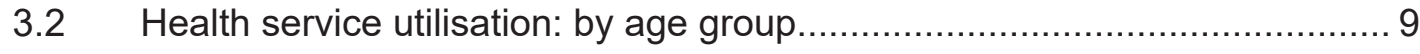

3.3 Public Health Nurse ........................................................................ 10

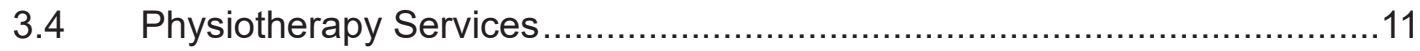

3.5 Home Care Services ................................................................... 12

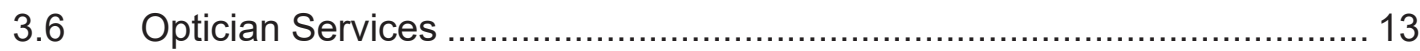

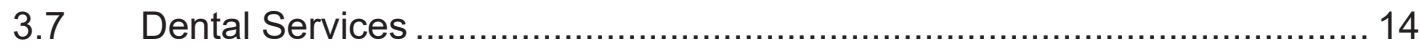

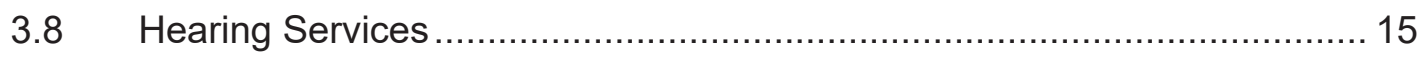

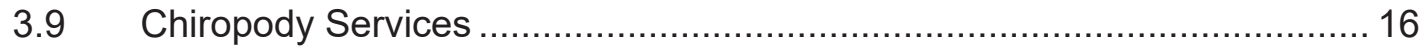

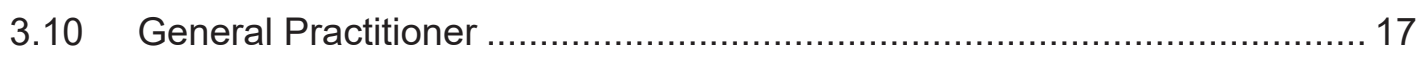

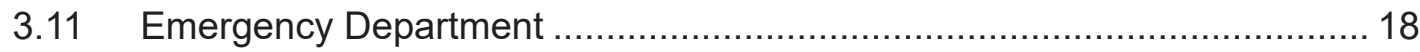

3.12 Average use of Healthcare Services ............................................... 19

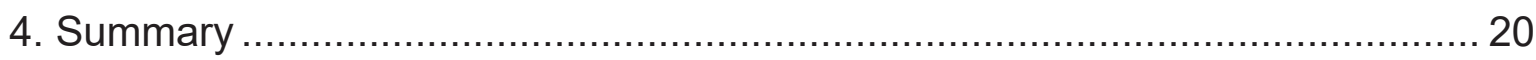

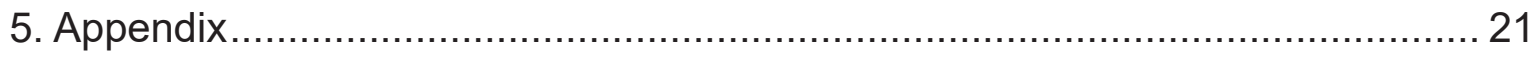

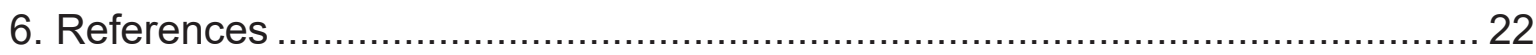




\section{HEALTH SERVICE UTILISATION BY OLDER ADULTS IN IRELAND}

USE OF COMMUNITY CARE SERVICES

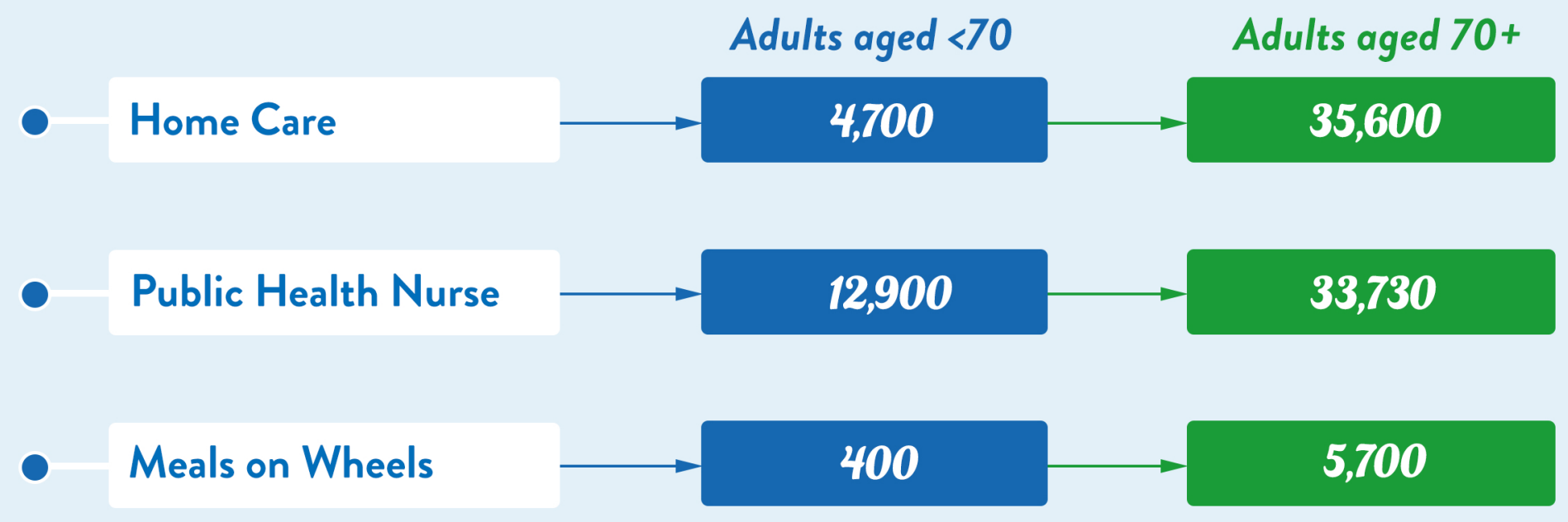

\section{USE OF MEDICAL CARE SERVICES}

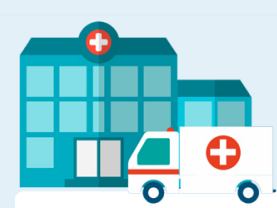

\section{EMERGENCY DEPARTMENT}

Adults aged $<70$

173,200 visited at least once in

the last year and average $\mathbf{0 . 2 3}$ visits

a year

Adults aged $70+$

$\mathbf{9 5 , 9 0 0}$ visited at least once in the last year and average $\mathbf{0 . 3 2}$ visits a year

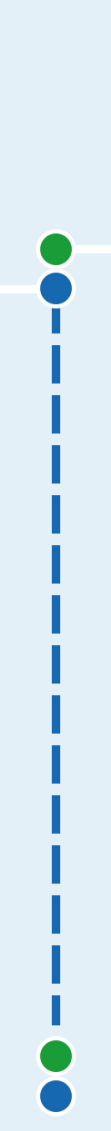

Adults aged 70+

35,600

\section{GENERAL PRACTITIONER}

Adults aged $<70$

$\mathbf{9 1 0 , 5 7 0}$ visited at least once in

the last year and average $\mathbf{3 . 4}$ visits

a year

Adults aged $70+$

413,600 visited at least once in the last year and average $\mathbf{4 . 4}$ visits

a year

\section{For more information please visit www.tilda.ie}

Supported by

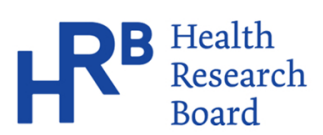

Science

Ireland 11
The
A T L A N T I C

Irish Life 


\section{Executive Summary}

\section{Rationale}

The purpose of this report is to examine social and health care service utilisation among older adults in the latest available wave (i.e. Wave 5) of The Irish Longitudinal Study on Ageing (TILDA) - both community and hospital services. These data were collected during the 2018 calendar year, and we provide corresponding estimated number of service users by using data from the latest available census in the Republic of Ireland (Census 2016).

We examine these data nationally, and by county and age group $(0=$ aged $50-69,1=$ aged $\geq 70$ ). We have selected these age groups in light of the focus of the Irish government on adults aged 70 or more as an at-risk group during the outbreak of COVID-19 in Ireland [1].

Our data show that service use in adults aged 50 and older is low; this is consistent with our previous reports [2], underscoring the fact that the majority aged 50 and over are active and make significant contributions to the social and economic fabric of Irish society. These contributions include, notably in the context of this report, the provision of informal care to their spouses, relatives, friends and neighbours [3].

The prevalence of frailty increases with age, from $11 \%$ in adults aged $\geq 50$, to $18.9 \%$ of adults aged $\geq 70$, according to the Fried phenotype [4] measure of frailty, and $28.1 \%$ of adults aged $\geq 70$ who live alone are frail [5]. Frailty and living arrangements often place older adults in need of support from health care services. Frailty places an older adult at increased risk of falls, disability or hospitalisation. Older adults who live alone and experience difficulty in daily activities (e.g. getting out of bed, going to the toilet) will require help from outside their home, such as an informal carer or State-provided home care, or services such as meals on wheels. In our data, only a small proportion of adults aged $\geq 70$ received services in their home, for example home care (8.35\%), the Public Health Nurse $(7.91 \%)$, meals on wheels $(1.33 \%)$ or home care package $(1.23 \%)$. By contrast, $97 \%$ reported having visited the General Practitioner at least once in the previous year.

Finally, while we report increased healthcare utilisation in older adults aged $\geq 70$, we note most of this relationship is explained by the older adults' biological age (e.g. frailty, disability, chronic disease) as opposed to their chronological age [6, 7]. 


\section{Key Findings}

- The most commonly used service by older adults is their General Practitioner (GP). $93 \%$ of the population aged $\geq 50$ (approximately $1,346,370$ people) reported seeing their GP at least once in the previous 12 months, increasing to $97 \%$ among adults aged $\geq 70$ (approximately 413,630 people). Adults aged $\geq 50$ made on average 3.9 visits to their GP in the previous year. This figure changed by age group, to 3.4 visits for adults aged 50 to 69 , and 4.4 visits for adults aged $\geq 70$.

- A larger proportion of adults aged $\geq 70$ years use home care and the public Health Nurse (PHN) service compared to adults aged $\geq 50.4 .3 \%$ of adults aged $\geq 50$ reported having received home care, increasing to $8.3 \%$ of adults aged $\geq 70$. Similarly, $4.5 \%$ of adults aged $\geq 50$ reported having received a visit from the PHN, increasing to $7.9 \%$ of adults aged $\geq 70$.

- The most frequently used of State-provided community services in 2018 were optician services, where nationally $14.6 \%$ (approx. 211,770 ) adults aged $\geq 50$ utilised this service.

- Speech and language therapy was the least used community service; 0.35\% (approx. 4,920 ) adults aged $\geq 50$ utilised this service in 2018.

- $19.7 \%$ of adults aged $\geq 50$ (approximately 284,810 people) reported visiting the Emergency Department (ED) at least once in the previous 12 months, increasing to $22.5 \%$ among adults aged $\geq 70$ (approximately 95,890 people). The average number of visits to the ED was 0.27 visits for adults aged $\geq 50,0.23$ for adults aged between 50 and 69 , and 0.32 for adults aged $\geq 70$.

- The average number of overnight hospital admissions was also associated with age; 0.28 for adults aged $\geq 50,0.20$ for adults aged between 50 and 69 , and 0.35 for adults aged $\geq 70$. 


\section{Introduction}

The aim of this report is to provide the estimated rate and number of service users of medical, social and community services, nationally and across each of the twenty-six counties in the Republic of Ireland. We will examine service use within the population aged 50 and over as a whole, and divided into adults aged 50 to 69 and adults aged 70 or more (herein aged $\geq 70$ ). We have chosen these age groups in keeping with Government guidance on cocooning to protect people over 70 years from COVID-19 [1].

A previous TILDA report, prepared in response to the outbreak of COVID-19 in Ireland, shows how frailty increases with age; $1.7 \%$ of adults aged $55-69$ are frail, rising to $9.8 \%$ of adults aged $70-74$ and $21.9 \%$ of adults aged $80-84$ [5]. The relationship between frailty, comorbidities, disabilities and age explains most of the relationship between age and increased health service utilisation $[6,7]$.

Nonetheless, in this particular context, it may be helpful for service planners and public health officials to understand how adults aged $\geq 70$ use hospital, primary and community care services across Ireland, as they develop strategies involving the deployment of health care workers and facilities to respond to the outbreak of COVID-19. 


\section{Methods}

\subsection{Sample}

In this report, we examine utilisation of services in Wave $5(2018)^{1}$ of the TILDA study and apply this to CSO data from the latest Census (2016). TILDA data are collected through the computer-assisted personal interview (CAPI).

Of the 8,504 participants aged $\geq 50$ years in TILDA at the baseline wave in 2009, 3,401 did not participate in Wave 5. 3 participants joined the study in Wave $5^{2}$. This left a sample of 5,106 participants at Wave 5 . We dropped from our analysis any participant aged less than 50 years of age $(n=19)^{3}$. Thus, the analytical sample included $n=5,087$ participants aged $\geq 50^{4}$ at Wave 5 (see Figure 1).

Figure 1. Study Flowchart

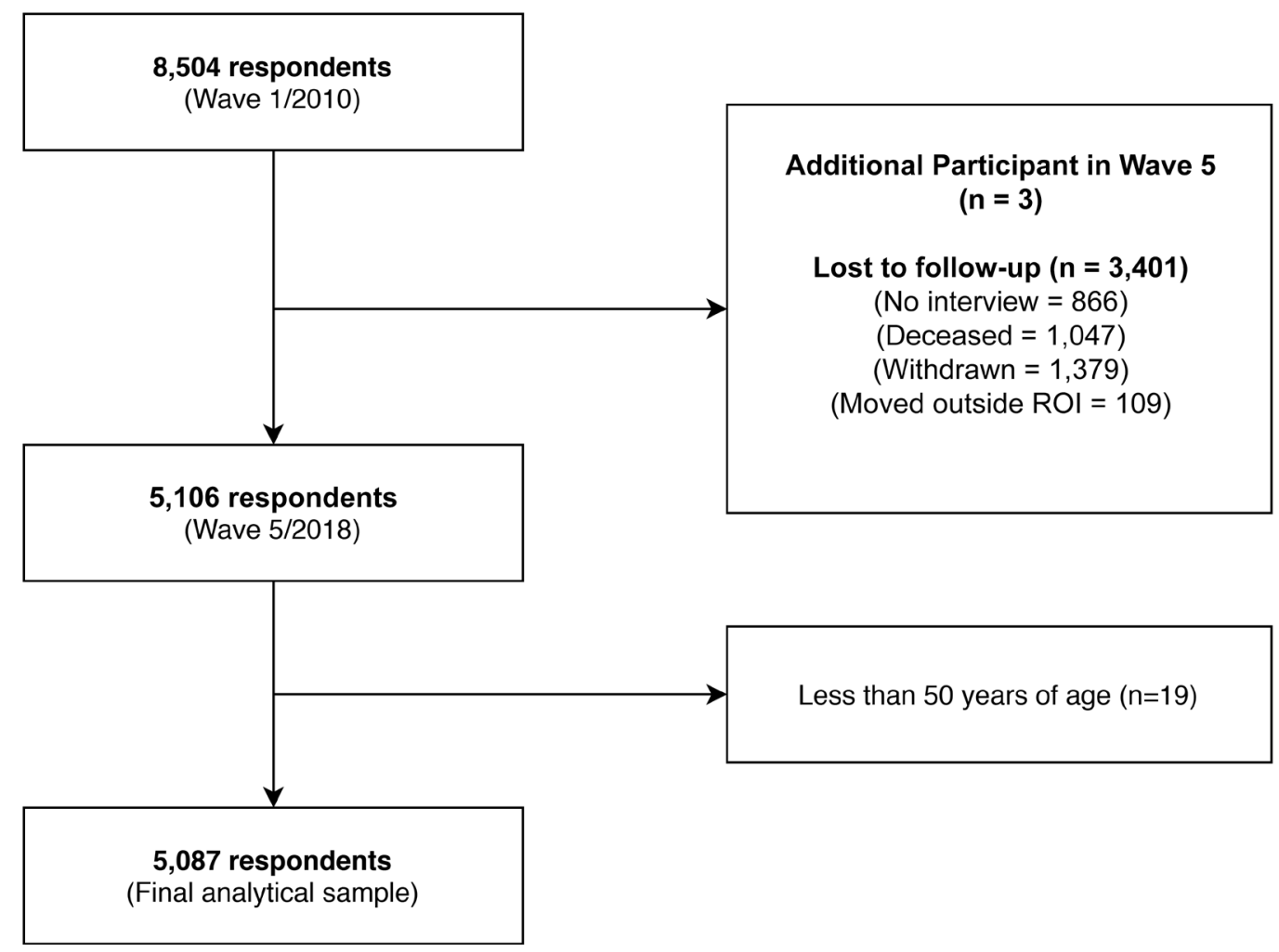

1 Data collection period: 16th January 2018 to 1 st January 2019

2 TILDA recruits at level of household, thus all household members are invited to participate in the study. Some people may not participate at wave 1 , but may choose to do so at subsequent waves.

$3 \quad$ Note: We kept in our sample participants who indicated they were resident in a nursing home for more than 12 months $(n=48)$

4 The average age of the sample was 69.91 years, with a minimum of 50 years and a maximum of 103 years 


\subsection{Study Weights}

Weights were used in all cases to make estimates relevant to the general population of over 50s in Ireland. In this instance, longitudinal weights which account for participant attrition between Wave 1 and Wave 5 were used. To calculate these weights, the underlying probability of being included in the computer-assisted personal interview (CAPI) was multiplied by the reciprocal of the probability of participating in all five TILDA waves. This probability was calculated using a logistic regression with the following predictors: age, sex, education level, age, marital status, geographic location, smoking status, health insurance, medications, socio-economic stratum, self-rated health, disabilities, depression, employment status, cardiovascular conditions, diabetes, vision, cognitive status and whether a person has wrist or hip fractures.

\subsection{Measures}

TILDA participants were asked to state the number of times they visited medical services, including the General Practitioner (GP), the Emergency Department (ED), the outpatient clinic, day case procedures and overnight hospital admissions in the previous twelve months. Those admitted to hospital were further asked to state how many nights they spent in hospital.

TILDA participants were also asked if they had utilised community-based allied health care services in the preceding twelve months - excluding any services for which they had paid anything other than a token or nominal amount. This included a range of social and community services provided by the state: physiotherapy, dietician, hearing, dental, optician, psychological/counselling services, social work services, home care ${ }^{5}$, home care package, community nursing ${ }^{6}$, meals on wheels, day centre care, occupational therapy and respite care.

\section{$2.4 \quad$ Analysis}

Firstly, we estimate the weighted percentage of older adults who used community services,

\footnotetext{
$5 \quad$ Includes home help (a person employed by State to help with household chores such as cleaning and cooking) and personal care (a person employed by the State to assist with bathing, showering, bodily care etc.).

6 "Includes Public Health Nurses, Community Registered General Nurses, Community Mental Health Nurses, Clinical Nurse Specialists and Advanced Nurse Practitioners"
} 
or made at least one visit to their GP, or made at least one visit to the ED. We then apply the weighted percentages from the TILDA study to the Census 2016 data, to estimate the number of older adults in receipt of services (to the nearest 10). See Table 1 for the denominators from Census 2016.

Table 1. Number of adults aged $\geq 50$ years (Sources: TILDA Wave 5; CSO Statbank (Census 2016))

\begin{tabular}{l|c|c} 
& TILDA & Census 2016 \\
No. & No. \\
Total aged 50 years or more & 5,087 & $1,446,460$ \\
\hline
\end{tabular}

Secondly, we estimate the weighted percentage of older adults who used community services, or made at least one visit to their GP, or made at least one visit to the ED, by cross tabulating the use of a service with a person's age group. ${ }^{7}$ We then apply the weighted percentages from the TILDA study to the Census 2016 data, to estimate the number of older adults in receipt of services (to the nearest 10) by age group. See Table 2 for the denominators from Census 2016.

Table 2. Number of adults aged $\geq 50$ years: by age group (Sources: TILDA Wave 5; CSO Statbank (Census 2016))

\begin{tabular}{|c|c|c|}
\hline & $\begin{array}{l}\text { TILDA } \\
\text { No. }\end{array}$ & $\begin{array}{c}\text { Census } 2016 \\
\text { No. }\end{array}$ \\
\hline Aged $50-69$ years & 2,648 & $1,020,129$ \\
\hline Aged 70 years or more & 2,439 & 426,331 \\
\hline Total aged 50 years or more & 5,087 & $1,446,460$ \\
\hline
\end{tabular}

Thirdly, we estimate the weighted percentage of older adults who used community services, or made at least one visit to their GP, or made at least one visit to the ED, by cross tabulating the use of a service with a person's age group. ${ }^{8}$ We then apply the weighted percentages from the TILDA study to the Census 2016 data, to estimate the number of older adults in receipt of services (to the nearest 10) by county. See Table 3 for the denominators from Census 2016.

\footnotetext{
$7 \quad$ Some of these services are used rarely; they would result in population estimates based on very low numbers with large confidence intervals. These variables have thus been dropped from the subgroup analysis by county $8 \quad$ Some of these services are used rarely; they would result in population estimates based on very low numbers with large confidence intervals. These variables have thus been dropped from the subgroup analysis by county
} 
Table 3. Number of adults aged $\geq 50$ years: by county (Sources: TILDA Wave 5; CSO Statbank (Census 2016))

\begin{tabular}{|c|c|c|}
\hline & $\begin{array}{l}\text { TILDA } \\
\text { No. }\end{array}$ & $\begin{array}{c}\text { Census } 2016 \\
\text { No. }\end{array}$ \\
\hline Carlow & 54 & 17,078 \\
\hline Cavan & 64 & 23,808 \\
\hline Clare & 122 & 39,764 \\
\hline Cork & 527 & 166,961 \\
\hline Donegal & 199 & 53,478 \\
\hline Dublin & 1,218 & 374,389 \\
\hline Galway & 286 & 78,657 \\
\hline Kerry & 231 & 54,129 \\
\hline Kildare & 114 & 57,361 \\
\hline Kilkenny & 104 & 31,927 \\
\hline Laois & 62 & 23,360 \\
\hline Leitrim & 41 & 11,650 \\
\hline Limerick & 224 & 61,221 \\
\hline Longford & 48 & 12,897 \\
\hline Louth & 90 & 37,239 \\
\hline Mayo & 270 & 48,728 \\
\hline Meath & 188 & 51,942 \\
\hline Monaghan & 83 & 19,337 \\
\hline Offaly & 89 & 24,305 \\
\hline Roscommon & 150 & 23,305 \\
\hline Sligo & 95 & 23,117 \\
\hline Tipperary & 211 & 53,939 \\
\hline Waterford & 146 & 38,331 \\
\hline Westmeath & 99 & 26,635 \\
\hline Wexford & 226 & 49,048 \\
\hline Wicklow & 146 & 43,854 \\
\hline National & 5,087 & $1,446,460$ \\
\hline
\end{tabular}

Our results should be interpreted as the rate of service use and an estimated number of people using these services, nationally, by age group and by county. For example, $7.91 \%$ (approx. 33,730) of older adults aged $\geq 70$ reported using the Public Health Nurse service in the previous twelve months.

Finally, we estimate the weighted average number of visits older adults made to the General Practitioner, the Emergency Department and to outpatient clinics; we also estimate the average number of overnight hospital admissions, day case procedures and 
nights spent in hospital in the previous twelve months, nationally, by age group and by county.

Limitations

- It is important to note that in many instances the disaggregation of health service utilisation by age, and by county, resulted in making estimates using very low number of TILDA cases, ${ }^{9}$ and so estimates have very wide confidence intervals and may not be reliable.

- The slight inaccuracies in age estimates, and rounding errors within each age range, mean the sum over age ranges may not equal the total.

- The rate and number of estimated service users may be slightly overestimated due to the differences in the age structure of the TILDA sample at Wave 5 in comparison to the age structure of the older population in Census 2016 (see Appendix).

9 TILDA case in this instance refers to a participant who reported having used a service. 


\section{Results}

\subsection{Health service utilisation: national estimates}

Table 2 below shows the weighted proportion of adults aged $\geq 50$ years who used a service in the previous 12 months, and the estimated number of older adults receiving these services in the population.

Table 4. Use of healthcare services in the previous 12 months in the population aged $\geq 50$ years $(n=1,446,460)$

\begin{tabular}{|l|c|c|}
\hline & \multicolumn{2}{|c|}{ Total aged $\mathbf{2 5 0}$ years } \\
\cline { 2 - 3 } & Weighted $\%$ & Population No. \\
\hline Public health nurse & $4.53 \%$ & 65,530 \\
\hline Occupational therapist & $1.17 \%$ & 16,890 \\
\hline Chiropodist & $4.97 \%$ & 71,910 \\
\hline Physiotherapist & $5.94 \%$ & 85,870 \\
\hline Speech and language therapist & $0.34 \%$ & 4,920 \\
\hline Home care & $4.34 \%$ & 62,780 \\
\hline Meals on wheels & $0.68 \%$ & 9,780 \\
\hline Home care package & $0.64 \%$ & 9,250 \\
\hline Respite & $0.36 \%$ & 5,210 \\
\hline Hearing & $2.57 \%$ & 37,180 \\
\hline Dental & $11.18 \%$ & 161,720 \\
\hline Social worker & $0.14 \%$ & 2,030 \\
\hline Psychological & $0.90 \%$ & 12,590 \\
\hline Day care & $0.96 \%$ & 13,890 \\
\hline Optician & $14.64 \%$ & 211,770 \\
\hline Dietitian & $0.88 \%$ & 12,730 \\
\hline$\geq 1$ visits to GP & $93.08 \%$ & $1,346,370$ \\
\hline$\geq 1$ visits to ED & $19.69 \%$ & 284,810 \\
\hline Not Dato & & \\
\hline
\end{tabular}

Note: Data from Wave 5 (2018) TILDA weighted to account for population, rounded to nearest 10. 
Table 5. Average use of healthcare services in the previous 12 months in the population aged $\geq 50$ years $(n=1,446,460)$

\begin{tabular}{l|c} 
& Aged $\geq 50$ years \\
& Mean \\
\hline General Practitioner & 3.88 \\
\hline Emergency Department & 0.27 \\
\hline Outpatient clinic & 1.67 \\
\hline Day case procedures & 0.10 \\
\hline Overnight hospital admissions & 0.28 \\
\hline Nights spent in hospital & 1.92 \\
\hline
\end{tabular}




\subsection{Health service utilisation: by age group}

Table 6. Use of healthcare services in the previous 12 months in the population aged $\geq 50$ years by age group $(n=1,446,460)$

\begin{tabular}{|c|c|c|c|c|}
\hline & \multicolumn{2}{|c|}{ Aged $50-69$ years } & \multicolumn{2}{|c|}{ Aged $\geq 70$ years } \\
\hline & Weighted \% & Population No. & Weighted \% & Population No. \\
\hline Public health nurse & $1.26 \%$ & 12,860 & $7.91 \%$ & 33,730 \\
\hline Occupational therapist & $0.88 \%$ & 8,980 & $1.46 \%$ & 6,230 \\
\hline Chiropodist & $1.11 \%$ & 11,330 & $8.96 \%$ & 38,200 \\
\hline Physiotherapist & $4.56 \%$ & 46,520 & $7.36 \%$ & 31,380 \\
\hline Speech and language therapist & $0.22 \%$ & 2,250 & $0.47 \%$ & 2,010 \\
\hline Home care & $0.46 \%$ & 4,700 & $8.35 \%$ & 35,600 \\
\hline Meals on wheels & $0.04 \%$ & 440 & $1.33 \%$ & 5,680 \\
\hline Home care package & $0.06 \%$ & 620 & $1.23 \%$ & 5,250 \\
\hline Respite & $0.14 \%$ & 1,430 & $0.59 \%$ & 2,520 \\
\hline Hearing & $1.36 \%$ & 13,780 & $3.83 \%$ & 16,330 \\
\hline Dental & $10.82 \%$ & 110,380 & $11.56 \%$ & 49,290 \\
\hline Social worker & $0.04 \%$ & 410 & $0.24 \%$ & 1,030 \\
\hline Psychological & $0.90 \%$ & 9,190 & $0.83 \%$ & 3,540 \\
\hline Day care & $0.27 \%$ & 2,760 & $1.67 \%$ & 7,120 \\
\hline Optician & $10.84 \%$ & 110,590 & $18.56 \%$ & 79,130 \\
\hline Dietitian & $1.01 \%$ & 10,310 & $0.74 \%$ & 3,160 \\
\hline$\geq 1$ visits to GP & $89.26 \%$ & 910,570 & $97.02 \%$ & 413,630 \\
\hline$\geq 1$ visits to $E D$ & $16.98 \%$ & 173,220 & $22.49 \%$ & 95,890 \\
\hline
\end{tabular}

Note: Data from Wave 5 (2018) TILDA weighted to account for population, rounded to nearest 10 . Totals may vary due to rounding and rounding error.

Table 7. Average use of healthcare services by age group in the previous 12 months in the population aged $\geq 50$ years $(n=1,446,460)$.

\begin{tabular}{|l|c|c|} 
& Aged $\mathbf{5 0}-\mathbf{6 9}$ years & Aged $\mathbf{Z 7 0}$ years \\
\hline General Practitioner & 3.39 & 4.39 \\
\hline Emergency department & 0.23 & 0.32 \\
\hline Outpatient clinic visits & 1.53 & 1.81 \\
\hline Day case procedures & 0.07 & 0.12 \\
\hline Overnight hospital admissions & 0.20 & 0.35 \\
\hline Nights spent in hospital & 1.24 & 2.64 \\
\hline
\end{tabular}




\subsection{Public Health Nurse}

Table 8. Use of Public Health Nurse in the previous 12 months by county in the population aged $\geq 50$ years $(n=1,446,460)$

\begin{tabular}{|c|c|c|}
\hline \multirow{2}{*}{ Public Health Nurse } & \multicolumn{2}{|c|}{ All aged $\geq 50$ years } \\
\hline & $\begin{array}{l}\text { TILDA } \\
\text { No. }\end{array}$ & $\begin{array}{c}\text { Census } 2016 \\
\text { No. }\end{array}$ \\
\hline Carlow & $6.89 \%$ & 1,180 \\
\hline Cavan & $2.27 \%$ & 540 \\
\hline Clare & $0.00 \%$ & NA \\
\hline Cork & $5.76 \%$ & 9,620 \\
\hline Donegal & $3.15 \%$ & 1,690 \\
\hline Dublin & $3.13 \%$ & 11,730 \\
\hline Galway & $7.86 \%$ & 6,190 \\
\hline Kerry & $1.97 \%$ & 1,070 \\
\hline Kildare & $4.78 \%$ & 2,750 \\
\hline Kilkenny & $6.77 \%$ & 2,170 \\
\hline Laois & $15.58 \%$ & 3,640 \\
\hline Leitrim & $8.52 \%$ & 1,000 \\
\hline Limerick & $8.18 \%$ & 5,010 \\
\hline Longford & $13.46 \%$ & 1,740 \\
\hline Louth & $5.91 \%$ & 2,200 \\
\hline Mayo & $3.51 \%$ & 1,720 \\
\hline Meath & $0.40 \%$ & 210 \\
\hline Monaghan & $7.60 \%$ & 1,480 \\
\hline Offaly & $7.95 \%$ & 1,940 \\
\hline Roscommon & $8.55 \%$ & 2,000 \\
\hline Sligo & $3.37 \%$ & 780 \\
\hline Tipperary & $1.83 \%$ & 990 \\
\hline Waterford & $1.35 \%$ & 520 \\
\hline Westmeath & $2.11 \%$ & 570 \\
\hline Wexford & $5.62 \%$ & 2,760 \\
\hline Wicklow & $6.79 \%$ & 2,980 \\
\hline National & $4.53 \%$ & 65,530 \\
\hline
\end{tabular}

Note: Data from Wave 5 (2018) TILDA weighted to account for population, rounded to nearest 10 . Totals may vary due to rounding. 


\subsection{Physiotherapy Services}

Table 9. Use of physiotherapy services in the previous 12 months by county in the population aged $\geq 50$ years $(n=1,446,460)$

\begin{tabular}{|c|c|c|}
\hline \multirow{2}{*}{ Physiotherapy } & \multicolumn{2}{|c|}{ All aged $\geq 50$ years } \\
\hline & $\begin{array}{l}\text { TILDA } \\
\text { No. }\end{array}$ & $\begin{array}{c}\text { Census } 2016 \\
\text { No. }\end{array}$ \\
\hline Carlow & $9.88 \%$ & 1,690 \\
\hline Cavan & $6.53 \%$ & 1,560 \\
\hline Clare & $4.26 \%$ & 1,700 \\
\hline Cork & $5.92 \%$ & 9,880 \\
\hline Donegal & $8.65 \%$ & 4,630 \\
\hline Dublin & $5.00 \%$ & 18,720 \\
\hline Galway & $5.36 \%$ & 4,220 \\
\hline Kerry & $4.17 \%$ & 2,260 \\
\hline Kildare & $3.92 \%$ & 2,250 \\
\hline Kilkenny & $10.69 \%$ & 3,420 \\
\hline Laois & $8.53 \%$ & 2,000 \\
\hline Leitrim & $16.75 \%$ & 1,960 \\
\hline Limerick & $3.43 \%$ & 2,110 \\
\hline Longford & $5.62 \%$ & 730 \\
\hline Louth & $10.75 \%$ & 4,010 \\
\hline Mayo & $6.68 \%$ & 3,260 \\
\hline Meath & $5.39 \%$ & 2,810 \\
\hline Monaghan & $9.16 \%$ & 1,780 \\
\hline Offaly & $10.01 \%$ & 2,440 \\
\hline Roscommon & $5.90 \%$ & 1,380 \\
\hline Sligo & $8.49 \%$ & 1,970 \\
\hline Tipperary & $3.97 \%$ & 2,150 \\
\hline Waterford & $1.63 \%$ & 630 \\
\hline Westmeath & $3.58 \%$ & 960 \\
\hline Wexford & $9.71 \%$ & 4,770 \\
\hline Wicklow & $4.98 \%$ & 2,190 \\
\hline National & $5.94 \%$ & 85,870 \\
\hline
\end{tabular}

Note: Data from Wave 5 (2018) TILDA weighted to account for population, rounded to nearest 10 . Totals may vary due to rounding. 


\subsection{Home Care Services}

Table 10. Use of home care services in the previous 12 months by county in the population aged $\geq 50$ years $(n=1,446,460)$

\begin{tabular}{|c|c|c|}
\hline \multirow{2}{*}{ Home Care } & \multicolumn{2}{|c|}{ All aged $\geq 50$ years } \\
\hline & $\begin{array}{l}\text { TILDA } \\
\text { No. }\end{array}$ & $\begin{array}{c}\text { Census } 2016 \\
\text { No. }\end{array}$ \\
\hline Carlow & $9.46 \%$ & 1,620 \\
\hline Cavan & $1.55 \%$ & 370 \\
\hline Clare & $2.61 \%$ & 1,040 \\
\hline Cork & $4.15 \%$ & 6,930 \\
\hline Donegal & $5.55 \%$ & 2,970 \\
\hline Dublin & $2.78 \%$ & 10,410 \\
\hline Galway & $7.10 \%$ & 5,590 \\
\hline Kerry & $0.29 \%$ & 160 \\
\hline Kildare & $0.93 \%$ & 540 \\
\hline Kilkenny & $1.17 \%$ & 380 \\
\hline Laois & $7.20 \%$ & 1,690 \\
\hline Leitrim & $7.04 \%$ & 820 \\
\hline Limerick & $7.72 \%$ & 4,730 \\
\hline Longford & $5.82 \%$ & 760 \\
\hline Louth & $3.97 \%$ & 1,480 \\
\hline Mayo & $2.76 \%$ & 1,350 \\
\hline Meath & $6.02 \%$ & 3,130 \\
\hline Monaghan & $9.48 \%$ & 1,840 \\
\hline Offaly & $3.97 \%$ & 970 \\
\hline Roscommon & $5.39 \%$ & 1,260 \\
\hline Sligo & $2.31 \%$ & 540 \\
\hline Tipperary & $4.74 \%$ & 2,560 \\
\hline Waterford & $4.26 \%$ & 1,640 \\
\hline Westmeath & $5.54 \%$ & 1,480 \\
\hline Wexford & $9.87 \%$ & 4,850 \\
\hline Wicklow & $4.00 \%$ & 1,760 \\
\hline National & $4.43 \%$ & 62,780 \\
\hline
\end{tabular}

Note: Data from Wave 5 (2018) TILDA weighted to account for population, rounded to nearest 10 . Totals may vary due to rounding. 


\subsection{Optician Services}

Table 11. Use of optician services in the previous 12 months by county in the population aged $\geq 50$ years $(n=1,446,460)$

\begin{tabular}{|l|c|c|}
\hline \multirow{2}{*}{ Optician } & \multicolumn{2}{|c}{ All aged $\geq 50$ years } \\
\cline { 2 - 3 } & $\begin{array}{c}\text { TILDA } \\
\text { No. }\end{array}$ & $\begin{array}{c}\text { Census } 2016 \\
\text { No. }\end{array}$ \\
\hline Carlow & $18.74 \%$ & 3,210 \\
\hline Cavan & $10.94 \%$ & 2,610 \\
\hline Clare & $0.00 \%$ & NA \\
\hline Cork & $14.93 \%$ & 24,930 \\
\hline Donegal & $27.33 \%$ & 14,620 \\
\hline Dublin & $10.91 \%$ & 40,850 \\
\hline Galway & $18.22 \%$ & 14,340 \\
\hline Kerry & $17.50 \%$ & 9,480 \\
\hline Kildare & $9.20 \%$ & 5,280 \\
\hline Kilkenny & $15.39 \%$ & 4,920 \\
\hline Laois & $19.43 \%$ & 4,540 \\
\hline Leitrim & $27.59 \%$ & 3,220 \\
\hline Limerick & $10.61 \%$ & 6,500 \\
\hline Longford & $19.11 \%$ & 2,470 \\
\hline Louth & $17.14 \%$ & 6,390 \\
\hline Mayo & $15.90 \%$ & 7,750 \\
\hline Meath & $15.29 \%$ & 7,950 \\
\hline Monaghan & $10.99 \%$ & 2,130 \\
\hline Offaly & $18.66 \%$ & 4,540 \\
\hline Roscommon & $30.92 \%$ & 7,210 \\
\hline Sligo & $21.36 \%$ & 4,940 \\
\hline Tipperary & $12.26 \%$ & 6,620 \\
\hline Waterford & $8.86 \%$ & 3,400 \\
\hline Westmeath & $12.64 \%$ & 3,370 \\
\hline Wexford & $22.93 \%$ & 11,250 \\
\hline Wicklow & $4.94 \%$ & 2,170 \\
\hline National & $\mathbf{1 4 . 6 4 \%}$ & $\mathbf{2 1 1 , 7 7 0}$ \\
\hline
\end{tabular}

Note: Data from Wave 5 (2018) TILDA weighted to account for population, rounded to nearest 10 . Totals may vary due to rounding. 


\subsection{Dental Services}

Table 12. Use of dental services in the previous 12 months by county in the population aged $\geq 50$ years $(n=1,446,460)$

\begin{tabular}{l|c|c|}
\multirow{2}{*}{ Dental Services } & \multicolumn{2}{|c}{ All aged $\mathbf{2 5 0}$ years } \\
\cline { 2 - 3 } & $\begin{array}{c}\text { TILDA } \\
\text { No. }\end{array}$ & $\begin{array}{c}\text { Census } 2016 \\
\text { No. }\end{array}$ \\
\hline Carlow & $12.04 \%$ & 2,060 \\
\hline Cavan & $3.30 \%$ & 790 \\
\hline Clare & $0.00 \%$ & NA \\
\hline Cork & $18.35 \%$ & 30,640 \\
\hline Donegal & $11.46 \%$ & 6,130 \\
\hline Dublin & $9.85 \%$ & 36,900 \\
\hline Galway & $8.64 \%$ & 6,800 \\
\hline Kerry & $11.83 \%$ & 6,410 \\
\hline Kildare & $11.11 \%$ & 6,380 \\
\hline Kilkenny & $11.18 \%$ & 3,570 \\
\hline Laois & $12.03 \%$ & 2,820 \\
\hline Leitrim & $17.75 \%$ & 2,070 \\
\hline Limerick & $6.68 \%$ & 4,100 \\
\hline Longford & $14.00 \%$ & 1,810 \\
\hline Louth & $20.55 \%$ & 7,660 \\
\hline Mayo & $11.23 \%$ & 5,480 \\
\hline Meath & $13.39 \%$ & 6,960 \\
\hline Monaghan & $6.06 \%$ & 1,180 \\
\hline Offaly & $13.08 \%$ & 3,180 \\
\hline Roscommon & $14.14 \%$ & 3,300 \\
\hline Sligo & $8.54 \%$ & 1,980 \\
\hline Tipperary & $9.17 \%$ & 4,950 \\
\hline Waterford & $5.99 \%$ & 2,300 \\
\hline Westmeath & $10.13 \%$ & 2,700 \\
\hline Wexford & $18.95 \%$ & 9,300 \\
\hline Wicklow & $5.74 \%$ & 2,520 \\
\hline National & $11.18 \%$ & 1,720 \\
\hline
\end{tabular}

Note: Data from Wave 5 (2018) TILDA weighted to account for population, rounded to nearest 10 . Totals may vary due to rounding. 


\subsection{Hearing Services}

Table 13. Use of hearing services in the previous 12 months by county in the population aged $\geq 50$ years $(n=1,446,460)$

\begin{tabular}{|c|c|c|}
\hline \multirow[b]{2}{*}{ Optician } & \multicolumn{2}{|c|}{ All aged $\geq 50$ years } \\
\hline & $\begin{array}{l}\text { TILDA } \\
\text { No. }\end{array}$ & $\begin{array}{c}\text { Census } 2016 \\
\text { No. }\end{array}$ \\
\hline Carlow & $7.40 \%$ & 1,270 \\
\hline Cavan & $0.00 \%$ & NA \\
\hline Clare & $0.00 \%$ & NA \\
\hline Cork & $1.90 \%$ & 3,180 \\
\hline Donegal & $4.55 \%$ & 2,440 \\
\hline Dublin & $3.01 \%$ & 11,260 \\
\hline Galway & $1.19 \%$ & 940 \\
\hline Kerry & $2.30 \%$ & 1,250 \\
\hline Kildare & $0.48 \%$ & 280 \\
\hline Kilkenny & $1.02 \%$ & 330 \\
\hline Laois & $1.37 \%$ & 320 \\
\hline Leitrim & $0.00 \%$ & NA \\
\hline Limerick & $2.02 \%$ & 1,240 \\
\hline Longford & $8.17 \%$ & 1,060 \\
\hline Louth & $0.44 \%$ & 170 \\
\hline Mayo & $5.14 \%$ & 2,510 \\
\hline Meath & $0.54 \%$ & 290 \\
\hline Monaghan & $0.00 \%$ & NA \\
\hline Offaly & $0.00 \%$ & NA \\
\hline Roscommon & $6.27 \%$ & 1,470 \\
\hline Sligo & $15.51 \%$ & 3,590 \\
\hline Tipperary & $2.26 \%$ & 1,220 \\
\hline Waterford & $1.27 \%$ & 490 \\
\hline Westmeath & $0.00 \%$ & NA \\
\hline Wexford & $1.87 \%$ & 920 \\
\hline Wicklow & $0.68 \%$ & 300 \\
\hline National & $2.57 \%$ & 37,180 \\
\hline
\end{tabular}

Note: Data from Wave 5 (2018) TILDA weighted to account for population, rounded to nearest 10 . Totals may vary due to rounding. 


\subsection{Chiropody Services}

Table 14. Use of chiropody services in the previous 12 months by county in the population aged $\geq 50$ years $(n=1,446,460)$

\begin{tabular}{|c|c|c|}
\hline \multirow{2}{*}{ Chiropody } & \multicolumn{2}{|c|}{ All aged $\geq 50$ years } \\
\hline & $\begin{array}{l}\text { TILDA } \\
\text { No. }\end{array}$ & $\begin{array}{c}\text { Census } 2016 \\
\text { No. }\end{array}$ \\
\hline Carlow & $9.12 \%$ & 1,560 \\
\hline Cavan & $1.12 \%$ & 270 \\
\hline Clare & $0.00 \%$ & NA \\
\hline Cork & $4.62 \%$ & 7,710 \\
\hline Donegal & $9.42 \%$ & 5,040 \\
\hline Dublin & $7.55 \%$ & 28,280 \\
\hline Galway & $3.36 \%$ & 2,650 \\
\hline Kerry & $4.51 \%$ & 2,450 \\
\hline Kildare & $4.09 \%$ & 2,350 \\
\hline Kilkenny & $1.09 \%$ & 350 \\
\hline Laois & $8.74 \%$ & 2,050 \\
\hline Leitrim & $6.80 \%$ & 800 \\
\hline Limerick & $4.82 \%$ & 2,960 \\
\hline Longford & $4.33 \%$ & 560 \\
\hline Louth & $4.04 \%$ & 1,510 \\
\hline Mayo & $1.10 \%$ & 540 \\
\hline Meath & $2.74 \%$ & 1,430 \\
\hline Monaghan & $3.12 \%$ & 610 \\
\hline Offaly & $5.33 \%$ & 1,300 \\
\hline Roscommon & $6.85 \%$ & 1,600 \\
\hline Sligo & $6.49 \%$ & 1,500 \\
\hline Tipperary & $2.25 \%$ & 1,220 \\
\hline Waterford & $1.33 \%$ & 510 \\
\hline Westmeath & $4.54 \%$ & 1,210 \\
\hline Wexford & $1.34 \%$ & 660 \\
\hline Wicklow & $8.38 \%$ & 3,680 \\
\hline National & $4.97 \%$ & 71,910 \\
\hline
\end{tabular}

Note: Data from Wave 5 (2018) TILDA weighted to account for population, rounded to nearest 10 . Totals may vary due to rounding. 


\subsection{General Practitioner}

Table 15. At least 1 visit to the GP in the previous 12 months by county in the population aged $\geq 50$ years $(n=1,446,460)$

\begin{tabular}{|c|c|c|}
\hline \multirow{2}{*}{$\begin{array}{l}\geq 1 \text { visits to the } \\
\text { General Practitioner }\end{array}$} & \multicolumn{2}{|c|}{ All aged $\geq 50$ years } \\
\hline & $\begin{array}{l}\text { TILDA } \\
\text { No. }\end{array}$ & $\begin{array}{c}\text { Census } 2016 \\
\text { No. }\end{array}$ \\
\hline Carlow & $87.13 \%$ & 14,890 \\
\hline Cavan & $94.43 \%$ & 22,490 \\
\hline Clare & $93.88 \%$ & 37,340 \\
\hline Cork & $93.69 \%$ & 156,430 \\
\hline Donegal & $91.02 \%$ & 48,680 \\
\hline Dublin & $93.01 \%$ & 348,220 \\
\hline Galway & $96.22 \%$ & 75,690 \\
\hline Kerry & $91.04 \%$ & 49,280 \\
\hline Kildare & $93.32 \%$ & 53,530 \\
\hline Kilkenny & $93.56 \%$ & 29,880 \\
\hline Laois & $95.47 \%$ & 22,310 \\
\hline Leitrim & $88.62 \%$ & 10,330 \\
\hline Limerick & $95.15 \%$ & 58,260 \\
\hline Longford & $85.41 \%$ & 11,020 \\
\hline Louth & $84.66 \%$ & 31,530 \\
\hline Mayo & $93.22 \%$ & 45,430 \\
\hline Meath & $92.76 \%$ & 48,190 \\
\hline Monaghan & $92.17 \%$ & 17,830 \\
\hline Offaly & $93.14 \%$ & 22,640 \\
\hline Roscommon & $92.39 \%$ & 21,540 \\
\hline Sligo & $93.64 \%$ & 21,650 \\
\hline Tipperary & $90.61 \%$ & 48,880 \\
\hline Waterford & $94.39 \%$ & 36,190 \\
\hline Westmeath & $96.22 \%$ & 25,630 \\
\hline Wexford & $96.21 \%$ & 47,190 \\
\hline Wicklow & $92.17 \%$ & 40,430 \\
\hline National & $93.08 \%$ & $1,346,370$ \\
\hline
\end{tabular}

Note: Data from Wave 5 (2018) TILDA weighted to account for population, rounded to nearest 10 . Totals may vary due to rounding. 


\subsection{Emergency Department}

Table 16. At least 1 visit to the ED in the previous 12 months by county in the population aged $\geq 50$ years $(n=1,446,460)$

\begin{tabular}{|c|c|c|}
\hline \multirow{2}{*}{$\begin{array}{l}\geq 1 \text { visits to the } \\
\text { Emergency Department }\end{array}$} & \multicolumn{2}{|c|}{ All aged $\geq 50$ years } \\
\hline & $\begin{array}{l}\text { TILDA } \\
\text { No. }\end{array}$ & $\begin{array}{c}\text { Census } 2016 \\
\text { No. }\end{array}$ \\
\hline Carlow & $21.28 \%$ & 3,640 \\
\hline Cavan & $24.35 \%$ & 5,800 \\
\hline Clare & $13.12 \%$ & 5,220 \\
\hline Cork & $17.57 \%$ & 29,340 \\
\hline Donegal & $17.53 \%$ & 9,380 \\
\hline Dublin & $23.56 \%$ & 88,210 \\
\hline Galway & $17.87 \%$ & 14,060 \\
\hline Kerry & $11.12 \%$ & 6,020 \\
\hline Kildare & $19.37 \%$ & 11,120 \\
\hline Kilkenny & $13.64 \%$ & 4,360 \\
\hline Laois & $21.21 \%$ & 4,960 \\
\hline Leitrim & $18.44 \%$ & 2,150 \\
\hline Limerick & $18.99 \%$ & 11,630 \\
\hline Longford & $16.51 \%$ & 2,130 \\
\hline Louth & $21.41 \%$ & 7,980 \\
\hline Mayo & $17.59 \%$ & 8,580 \\
\hline Meath & $23.32 \%$ & 12,120 \\
\hline Monaghan & $15.26 \%$ & 2,960 \\
\hline Offaly & $21.19 \%$ & 5,160 \\
\hline Roscommon & $17.55 \%$ & 4,100 \\
\hline Sligo & $20.13 \%$ & 4,660 \\
\hline Tipperary & $20.42 \%$ & 11,020 \\
\hline Waterford & $25.04 \%$ & 9,600 \\
\hline Westmeath & $17.92 \%$ & 4,780 \\
\hline Wexford & $16.92 \%$ & 8,300 \\
\hline Wicklow & $20.35 \%$ & 8,930 \\
\hline National & $19.69 \%$ & 284,810 \\
\hline
\end{tabular}

Note: Data from Wave 5 (2018) TILDA weighted to account for population, rounded to nearest 10 . Totals may vary due to rounding. 


\subsection{Average use of Healthcare Services}

Table 17. Average number of uses of healthcare services in the previous 12 months by county in the population aged $\geq 50$ years $(n=1,446,460)$

\begin{tabular}{|c|c|c|c|c|c|c|}
\hline & $\begin{array}{c}\text { GP } \\
\text { visits } \\
\text { (mean) }\end{array}$ & $\begin{array}{c}\text { ED } \\
\text { visits } \\
\text { (mean) }\end{array}$ & $\begin{array}{l}\text { Outpatient } \\
\text { clinic visits } \\
\text { (mean) }\end{array}$ & $\begin{array}{l}\text { Day } \\
\text { case } \\
\text { (mean) }\end{array}$ & $\begin{array}{l}\text { Hospital } \\
\text { admissions } \\
\text { (mean) }\end{array}$ & $\begin{array}{c}\text { Nights in } \\
\text { hospital } \\
\text { (mean) }\end{array}$ \\
\hline Carlow & 5.46 & 0.23 & 0.81 & 0.08 & 0.25 & 4.77 \\
\hline Cavan & 3.93 & 0.33 & 2.44 & 0.07 & 0.16 & 3.02 \\
\hline Clare & 4.14 & 0.19 & 0.54 & 0.07 & 0.26 & 1.14 \\
\hline Cork & 4.24 & 0.23 & 1.74 & 0.09 & 0.32 & 1.83 \\
\hline Donegal & 3.73 & 0.28 & 0.95 & 0.09 & 0.25 & 2.26 \\
\hline Dublin & 3.77 & 0.36 & 2.50 & 0.12 & 0.36 & 2.61 \\
\hline Galway & 4.41 & 0.22 & 1.16 & 0.12 & 0.25 & 1.66 \\
\hline Kerry & 3.72 & 0.15 & 1.16 & 0.10 & 0.23 & 1.17 \\
\hline Kildare & 2.87 & 0.20 & 2.61 & 0.08 & 0.26 & 0.74 \\
\hline Kilkenny & 3.69 & 0.16 & 1.33 & 0.08 & 0.30 & 1.91 \\
\hline Laois & 3.63 & 0.36 & 2.19 & 0.04 & 0.27 & 0.96 \\
\hline Leitrim & 4.19 & 0.33 & 0.99 & 0.13 & 0.56 & 8.91 \\
\hline Limerick & 4.80 & 0.25 & 1.35 & 0.15 & 0.30 & 2.16 \\
\hline Longford & 3.22 & 0.17 & 1.11 & 0.12 & 0.23 & 2.20 \\
\hline Louth & 3.23 & 0.34 & 1.44 & 0.09 & 0.32 & 1.12 \\
\hline Mayo & 4.23 & 0.22 & 1.34 & 0.12 & 0.19 & 1.59 \\
\hline Meath & 3.59 & 0.39 & 1.74 & 0.08 & 0.20 & 1.74 \\
\hline Monaghan & 3.04 & 0.19 & 1.29 & 0.13 & 0.26 & 1.14 \\
\hline Offaly & 3.53 & 0.37 & 1.04 & 0.07 & 0.27 & 3.61 \\
\hline Roscommon & 4.39 & 0.25 & 1.40 & 0.11 & 0.18 & 1.07 \\
\hline Sligo & 2.87 & 0.21 & 0.38 & 0.06 & 0.20 & 0.66 \\
\hline Tipperary & 3.68 & 0.27 & 1.70 & 0.05 & 0.21 & 1.08 \\
\hline Waterford & 4.15 & 0.29 & 1.48 & 0.08 & 0.22 & 0.83 \\
\hline Westmeath & 3.57 & 0.23 & 0.89 & 0.12 & 0.17 & 0.49 \\
\hline Wexford & 3.87 & 0.19 & 1.22 & 0.07 & 0.20 & 1.36 \\
\hline Wicklow & 3.07 & 0.32 & 1.67 & 0.12 & 0.23 & 1.82 \\
\hline
\end{tabular}

Note: Data from Wave 5 (2018) TILDA weighted to account for population, rounded to nearest 10 . Totals may vary due to rounding. 


\section{Summary}

Our data show that community service use in adults aged $\geq 50$ is low; this is consistent with our previous reports, underscoring the fact that the majority of adults aged $\geq 50$ and older are active and make significant contributions to the social and economic fabric of Irish society, for example providing essential informal care.

Our data also show the significant reach of general practice in Ireland, with the majority of older adults reporting having visited their GP at least once in the previous twelve months. From the perspective of the older population, it is essential general practice remains accessible to older adults during the COVID-19 outbreak.

We found $19.7 \%$ of adults aged $\geq 50$ reported visiting the ED at least once in the previous year, rising to $22.5 \%$ for adults aged $\geq 70$. We do not have data on reasons for attendance; however, it is important to ensure that older adults present in a timely manner to the ED, so that early prevention for stroke, heart and infections continues, and patients receive the early interventions which deliver better outcomes during the COVID-19 outbreak.

Finally, while only a small proportion of older adults aged $\geq 70$ access the Public Health Nurse or home care, these services are likely to play a vital role for those cocooning during the COVID-19 outbreak. 


\section{Appendix}

In order to understand these data we must be mindful of the differences between the TILDA and Census data. Notably, the weighted age structure of the older population in the TILDA study differs from that of the Census population (see Figure 2). TILDA is a longitudinal cohort study which follows the cohort of community-dwelling older adults aged $\geq 50$ years from 2009 onwards, while the Census is a survey capturing the entire population of Ireland in a given year.

Figure 2. Age distribution of the Census (2016) data and TILDA data (2018)

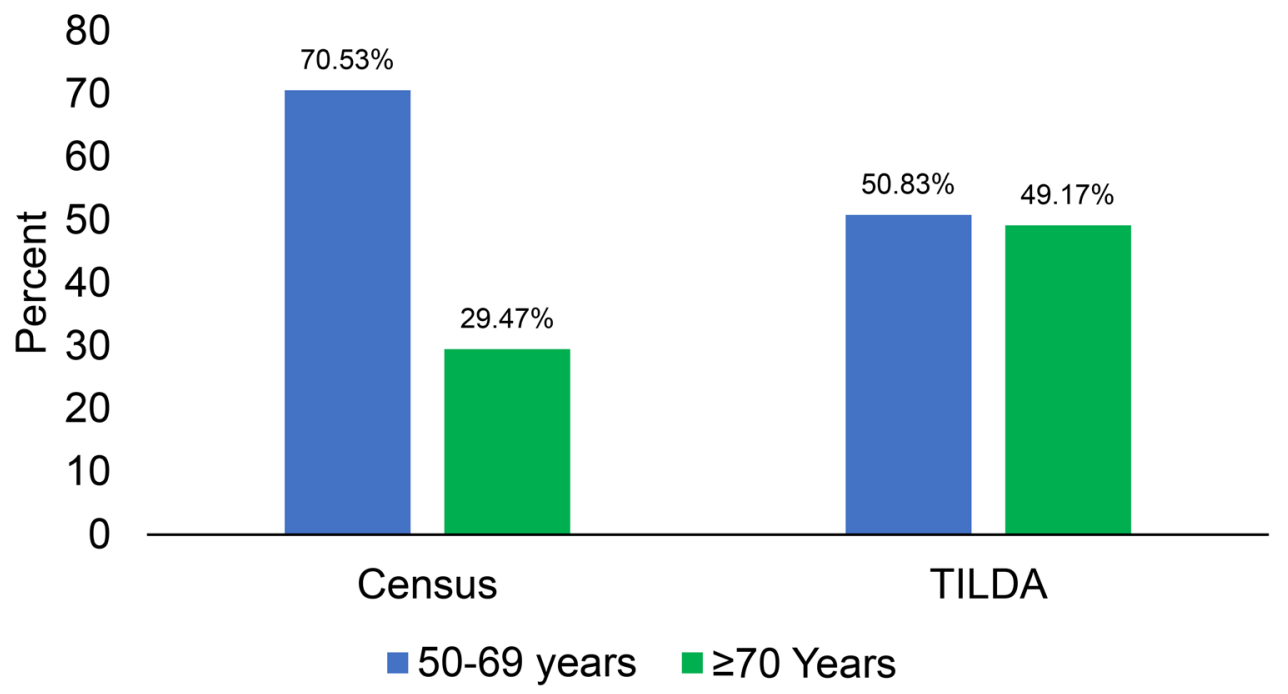

This means the national estimates from the TILDA data are likely to overestimate service use among the population aged 50 and over. Similarly, it is likely the data for the age group 50-69 years are an overestimate, as this group mostly comprises adults aged 57-69 years, as a result of the ageing of the TILDA cohort. Despite these limitations, it is important to remember that TILDA remains the only source of data to examine service use, across the whole system of care and by peoples' socioeconomic characteristics, in Ireland. 


\section{References}

1. Department of Health. Guidance on cocooning to protect people over 70 years and those extremely medically vulnerable from COVID-19. 2020; Available from: https:// www.gov.ie/en/publication/923825-guidance-on-cocooning-to-protect-people-over-70years-and-those-extr/.

2. Roe, L., et al., Trends in healthcare cover and healthcare use for older adults in Ireland during the austerity years of 2009 to 2016. 2018.

3. McGarrigle, C., et al., The Contributions of the Over 70s to Irish Society: Results from Wave 5 of the Irish Longitudinal Study on Ageing. 2020, The Irish Longitudinal Study on Ageing: Dublin.

4. Fried, L.P., et al., Frailty in older adults: evidence for a phenotype. Journal of Gerontology A Biological Sciences and Medical Sciences, 2001. 56(3): p. M146-56.

5. Kenny, R., et al., TILDA report to inform demographics for over 50 s in Ireland for COVID-19 crisis. 2020. https://www.doi.org/10.38018/TildaRe.2020-00

6. McDaid, O., The chronic ills of multimorbidity: a cross sectional examination of the prevalence, patterns and factors associated with multimorbidity in the Irish population aged 50 and over and its corresponding impact on health and social care utilisation, in School of Medicine. 2013, Trinity College Dublin.

7. Roe, L., et al., The impact of frailty on healthcare utilisation in Ireland: evidence from the Irish longitudinal study on ageing. BMC Geriatrics, 2017. 17(1): p. 203. 